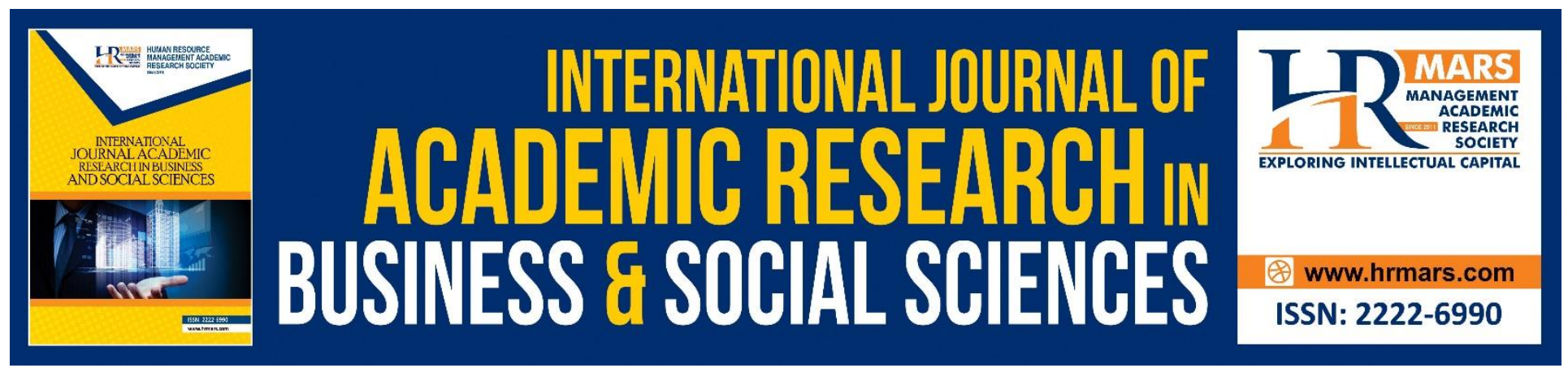

\title{
Influence of Nutritive Value Quality on Chefs' Food Preparation and Consumption
}

\section{Khairunnisa Mohamad Abdullah, Rosmaliza Muhammad, Muhammad Adib Mohamed Ramly, Mohd Salehuddin Mohd Zahari, Fadzilah Mohd Shariff}

To Link this Article: http://dx.doi.org/10.6007/IJARBSS/v11-i13/8511

DOI:10.6007/IJARBSS/v11-i13/8511

Received: 19 November 2020, Revised: 11 December 2020, Accepted: 05 January 2021

Published Online: 24 January 2021

In-Text Citation: (Abdullah et. al., 2021)

To Cite this Article: Abdullah, K. M., Muhammad, R., Ramly, M. A. M., Zahari, M. S. M., \& Shariff, F. M. (2021). Influence of Nutritive Value Quality on Chefs' Food Preparation and Consumption. International Journal of Academic Research in Business and Social Sciences, 11(13), 139-147.

\section{Copyright: (c) 2021 The Author(s)}

Published by Human Resource Management Academic Research Society (www.hrmars.com)

This article is published under the Creative Commons Attribution (CC BY 4.0) license. Anyone may reproduce, distribute, translate and create derivative works of this article (for both commercial and non-commercial purposes), subject to full attribution to the original publication and authors. The full terms of this license may be seen at: $\underline{\text { http://creativecommons.org/licences/by/4.0/legalcode }}$

Special Issue: Beyond 2020 and COVID-19 - New Perspective in the Hospitality \& Tourism Industry, 2021, Pg. 139 - 147

Full Terms \& Conditions of access and use can be found at http://hrmars.com/index.php/pages/detail/publication-ethics 


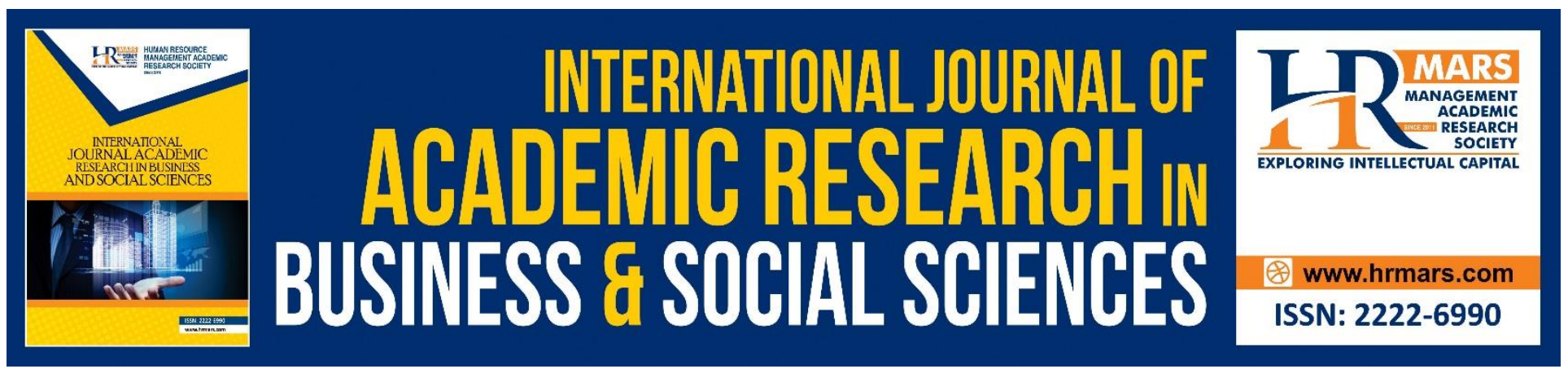

\title{
Influence of Nutritive Value Quality on Chefs' Food Preparation and Consumption
}

\section{Khairunnisa Mohamad Abdullah, Rosmaliza Muhammad, Muhammad Adib Mohamed Ramly, Mohd Salehuddin Mohd Zahari, Fadzilah Mohd Shariff}

Faculty of Hotel and Tourism Management, Universiti Teknologi MARA, Puncak Alam Campus, 42300, Selangor, Malaysia

\begin{abstract}
Nutritive value as part of food quality is the degree of a well-balanced vital nutrients of carbohydrates, protein, fat, vitamins and minerals in relation to the consumers' nutrient requirements. Choosing the right preparation methods and ingredients that contain high nutritive value is an important aspect of healthy eating in daily food consumption. Within food industries, food quality is acquainted especially among the food handlers, food service staff and chefs. Many people believe that most chefs with knowledge and skills of culinary education have awareness and concern regarding food quality, nutritional value, safety and hygiene in their daily food preparation and consumption. Thus, this study empirically examined the importance and influence of food nutritive value quality in terms of ingredients and cooking methods on chefs' daily food preparation and consumption. A descriptive research design using a quantitative approach was applied. A questionnaire-based survey was distributed to chefs who were directly involved in the food sectors within Klang Valley and had culinary educational background and experience. The findings showed that the quality of nutritive value in terms of ingredients and cooking methods played an important role in chefs' daily food preparation and consumption. Hence, it is important for the chefs to enhance the quality and taste of the food by using fresh ingredients and practice healthy cooking method. Besides that, their skills and knowledge can help to convey the information and promote the awareness of good eating habits to the society.
\end{abstract}

Keywords: Food Quality, Nutritive Value, Chefs, Food Preparation and Food Consumption.

\section{Introduction}

Food quality can be described as a crucial requirement to fulfill the expectation and needs of consumer (Peri, 2006). It is an important element of food consumption as consumers are increasingly conscious of food quality issue that relates to taste, environment, ethical and health concern (Zanoli, 
2004). Peri (2006) categorized food quality into three scopes which include sensory quality, food convenience and nutritive value. Barrett et al. (2010) mentioned that the growing demand for healthy food has increased the awareness among food manufacturers in creating diversity of food products that focuses on sensory quality and health benefits. However, the classification of food quality is too subjective and broad. Different individuals have distinct perception on food quality either they are grocers, athlete, students, nutritionist, farmers or retailers. This also goes with the culinarians and chefs. Food quality is typically familiar among the food service staff, food handlers and especially chefs as they generally have experience and knowledge pertaining to food quality matters (Pratten, 2003). In addition to training provided by employer, equipping the chefs with skill and knowledge is necessary to run the operation and system in workplace (Sommerville et al., 2007).

In line with that, with the advantage they have, they should play a significant role in helping and encouraging the society to consume good quality food as well as promoting good health and life especially among youth (Ibrahim, Ismail \& Mohammed, 2014). According to Pratten (2003), a good chef is not only because they can cook, but also be able to comprehend the effect of food on the palate, flavor and nutrition of food (Eves, Corney, Kipps, Lumbers, Price, \& Nob, 1996). In addition, having a profession as chefs, they should act as role models who can help people in their dietary consumption and preparation by contributing and sharing their knowledge, passion and creativity in producing and consuming high-quality food (Condrasky, Condrasky, Ledikwe, Flood, \& Rolls, 2007). Chef's knowledge and experience related to food nutrition and cooking skill can be very significant and helpful among the society in battling issues of diet-related disease such as obesity.

However, the accuracy of the above statement that mainly relates to the importance of nutritional value and chefs' daily food preparation and consumption remains ambiguous. Existing studies mostly focused on food consumption among other group professions such as nutritionist, model, nurse, student, athlete but not many studies have focused on chef (Horska \& Sparke, 2007). In other words, to what extend the importance of nutritional value quality in chefs' daily food preparation and consumption is not being intensely researched. Therefore, the purpose of this study is to investigate the influence of nutritional value quality attribute towards chefs' daily food preparation and consumption.

\section{Literature Review \\ Food Quality}

Food quality includes all valuable attributes that satisfy food buyer (Ferree, 1973). Schiefer and Deiter (2013) stated that food quality is an important aspect of buying decisions among consumers. The assurance of particular food quality requirements for raw ingredients and semi-finished foods is the requirement for attaining maximum qualities of end-product in a multistep manufacturing process. The food quality controls reliability partly depends on cost-intensive and time-consuming procedures and methods which influence their use and application. Hence, current emphasis was positioned on the expansion of cost effective that rapidly improved application in the food industries. Additionally, even though there are varieties of analytical methods available for the quality attributes measurement, their relation to consumer expectation remains a challenging task instead. 
Peri (2006) specified that food quality can be defined as necessities required to fulfill the expectations and needs of consumers. The researcher also categorized food quality into three scopes of general food quality model which are sensory quality, nutritive value and food convenience. The model contains elements of nutritional, safety, sensory conformity, production context, ethical, traceability, certification, information, packaging, availability, price and convenience. These elements are clustered into five requirement categories of product, guarantee, psychological, market system and packaging system (Peri, 2006).

\section{Nutritional Value}

What is nutritional value? Nutritional value can be described as a composition of food and it indicates the contribution to the nutrient component of the food (Eves, Corney, Kipps, Lumbers, Price, \& Noble, 1996). This value is subjected to the amount of food that is digested and absorbed and the quantity of important nutrients such as carbohydrates, protein, vitamins, fat and minerals contained therein. According to Peri (2006), this value can also be affected by the food handling and storage, soil and growing conditions and processing. Rickman, Bruhn and Barrett (2007) stated that nutritive value of food purely means the quality energy (calories), quantity and range, mineral, vitamins and phytochemicals that are found in food consumption. They also mentioned that protein, fat and carbohydrates are the sources of energy; and vitamins came from micronutrient; while minerals were from water, air or soil.

Food ingredients play a major role as it contains nutritive value that consumers need in daily food intake (Gharibyan, 2011). Rickman, J.C., Bruhn, C., \& Barrett, D.M. (2007) suggested that when choosing a recipe from the perspective of a partially fresh or purely fresh, freshness is held as the major consideration but an understanding of the parts that make up may include some of the best materials. Furthermore, natural food is often considered as a minimally processed food which does not contain any food additive or certain additives such as antibiotics, hormones, food colors, flavorings or sweeteners that are not originally in food (Ikerd, 2008).

According to Jarrard and Joe (2014), preparing and cooking meal at home will lead to a better control over the nutritional value and healthfulness on daily meals consumed. Bower, A. L. (1997) stated that fresh ingredient is very important in daily food consumption due to health concerns that contrast with food convenience which contains high sugar, fat, food preservatives, food additives, and salt. Healthy eating is not only about choosing good food but the preparation is also important. There are cooking methods which are better in cutting cholesterol, calories and fat while enhancing the nutritional value in food (Jarrard \& Joe, 2014). According to Gisslen (2015), there are two methods of cooking that is best suited for healthy cooking; the first is dry-heat method which means no liquid is required. It also means no steam, moisture, water, broth, wine or any other liquid is being used. Dry heat cooking method includes broiling, pan-frying, grilling, baking and it also involves deep-fat frying. The second method is moist-heat cooking which uses liquid, water or steam to convey the heat to food. Examples of moist-heat cooking method are stewing, pot roasting, braising, steaming, poaching, simmering, boiling, and en-papillote which is cooking using parchment paper. The healthy cooking method is by continuously boiling water and letting it turns into vapor or steam; the steam then transfers the heat to the adjacent food, thus cooking the food (Jarrard \& Joe, 2014). This cooking 
INTERNATIONAL JOURNAL OF ACADEMIC RESEARCH IN BUSINESS AND SOCIAL SCIENCES

Vol. 11, No. 13, Beyond 2021 and COVID-19 - New Perspective in the Hospitality \& Tourism Industry. 2021, E-ISSN: 2222-6990 @ 2021 HRMARS

method prevents loss of nutritional value, texture and shape of the food. The one that must be avoided is consuming food which is cooked by deep-fat frying and pan frying that is laden with fat.

\section{Food Preparation and Consumption}

Cooking is a process of transforming food ingredients that includes all the stages of food preparation and cooking methods (Bower, 1997). According to Usuramo (2000), food preparation involves the steps of preparing food ingredients for consumption, which usually need the range of combining and measurement of ingredients in an orderly process to attain a desirable product and it comprises but not restricted to cooking. This element has been classified by Muhammad et al. (2009) into different culture of a different country which has different techniques of preparing food. They also mentioned that food preparation techniques rely on the accessibility of the ingredients and cooking methods. Meanwhile, Gerbens-Leenes and Nonhebel (2002) clarified that food consumption pattern is actually the repetitive activities of eating that have been characterized by the kind, amount and combination of food items in their meals. The combination of food consumption is based on the three elements of sensory quality, nutritive value and food convenience which are complete. As mentioned by Olsen et al. (2002), sensory quality plays a key role and responses to products as apparent before the diners consume their meal. Food-characteristic assessment is by the perceptions of taste, texture, smell and appearance. Nutritive value is about vitamins, protein, carbohydrates, fat and minerals imbedded in food, while food convenience depends on the food price and preparation (Peri, 2006). Buckleya et al. (2007) referred food convenience as food product that requires less preparation time, easy to cook, simply obtainable, easy to handle, and has long shelf life.

\section{Methodology}

The main objective of this study is to empirically investigate the influence of nutritive value quality on chefs' daily food preparation and consumption; therefore, a quantitative research approach through cross sectional approach is considered a suitable method for data collection as it is able to explain the relevant attributes. The information needed for this study was obtained through self-administered questionnaire with chefs who are working in the food industry or culinary field. They are believed to be knowledgeable and have experience to provide relevant information on a particular subject. Due to the large number of chefs in Malaysia and the geographical dispersion, only those who are working in food sectors like restaurants and hotels within the Klang Valley area with culinary or food service educational background or/and experience were chosen as samples. Majority of the items in the questionnaire were adjusted from the past study that harps on the topic to accomplish the goal of the study. All of the information gathered was entered into Statistical Package for Social Science (SPSS) version 23 to decipher the information. During the process of information screening, only 201 were useful responses. In this manner, descriptive statistical examination was applied to figure the frequencies, rate, mean score and standard deviation as to report the data of the variables. The standard multiple regression was utilized in deciding how much variance in food preparation and consumption among chefs was described by the impact of nutritive value attributes. 
INTERNATIONAL JOURNAL OF ACADEMIC RESEARCH IN BUSINESS AND SOCIAL SCIENCES

Vol. 11, No. 13, Beyond 2021 and COVID-19 - New Perspective in the Hospitality \& Tourism Industry. 2021, E-ISSN: 2222-6990 @ 2021 HRMARS

\section{Result and Analysis}

\section{Influence of Nutritional Value Quality on Chefs' Food Preparation and Consumption}

This section of analysis looks into the second question objective of this study which is the influence of nutritive value on culinarians' food consumption. The mean score is depicted in Table 1 below.

Table 1: Mean score of the importance of Nutritive Value among Chefs

\begin{tabular}{lccc}
\hline \multicolumn{1}{c}{ Nutritive value } & Mean & Standard Deviation & N \\
\hline $\begin{array}{l}\text { I prefer to cook and eat fresh food ingredient } \\
\text { in my daily food consumption. }\end{array}$ & 4.3682 & .68832 & 201 \\
\hline $\begin{array}{l}\text { I often consume fresh ingredient in my daily } \\
\text { food consumption because it contains high }\end{array}$ & 4.3433 & .63763 & 201 \\
nutritive value. & & \\
\hline I believe that cooking method plays an & 4.4627 & .55664 & 201 \\
important role in healthy food consumption. & & .69715 & 201 \\
\hline I prefer healthy cooking method such as & 4.4279 & & \\
steam, simmering and boiling.
\end{tabular}

Table 1 reveals that nutritive value attributes are relatively important among the respondents. Most of the respondents agreed that cooking method is important for their health (Mean $=4.4627$, item 3). This is apparent as they prefer steaming, simmering and boiling cooking methods in their daily food preparation (Mean $=4.4279$, item 4). Furthermore, with the mean score of ( $M=4.3682$, item 1$)$, it showed that the respondents prefer to cook and eat fresh food ingredient and especially fresh ingredients that contain high nutritive value (Mean $=4.3433$, item 2 ).

\section{Food Preparation and Consumption among Chefs}

This section discusses the general food preparation and consumption among chefs. The respondents were required to answer each of the item relating to the general food preparation and consumption by using five-point Likert scale. The mean score and standard deviation were tabulated in the table below.

Table 2: Mean score of Food Preparation and Consumption among chefs

\begin{tabular}{lccc}
\hline \multicolumn{1}{c}{ Food Consumption } & Mean & Standard Deviation & N \\
\hline $\begin{array}{l}\text { I prefer to cook my own food instead of dining } \\
\text { outside because it is healthier and fresher. }\end{array}$ & 4.3234 & .63238 & 201 \\
\hline $\begin{array}{l}\text { My culinary knowledge and experience have } \\
\text { encouraged me to use and consume fresh food }\end{array}$ & 4.3532 & .64777 & 201 \\
$\begin{array}{l}\text { in my daily food consumption. } \\
\text { I believe convenience food usage is seen by me }\end{array}$ & 4.2836 & .63575. & 201 \\
$\begin{array}{l}\text { as degrading my culinary skills and knowledge. } \\
\text { My culinary knowledge and experience have }\end{array}$ & 4.3383 & .67452 & 201 \\
$\begin{array}{l}\text { contributed to have better food consumption } \\
\text { and healthy cooking habits. }\end{array}$ & & & \\
\hline
\end{tabular}


Results show that majority of the respondents indicated they are concerned with daily food preparation and consumption. They agreed that culinary knowledge and experience have encouraged them to use and consume fresh food in their daily food preparation and consumption (Mean $=4.3532$, item 2). Their culinary knowledge and experience have contributed them to have better food consumption and healthy cooking habits (Mean $=4.3383$, item 4 ). With that, they prefer to cook their own food instead of dining outside due to the healthier and fresher of the ingredients (Mean $=4.3234$, item 1). They also believed that the consumption of convenience food degrades their culinary skills and knowledge toward their food preparation and consumption (Mean $=4.2836$, item 3).

\section{Relationship between Nutritional Value Quality and Chefs' Food Preparation and Consumption}

The relationship between Nutritional Value quality and chefs' daily food preparation and consumption was further confirmed with standard multiple regression. The beta value under standardized coefficient was evaluated by comparing the contribution of the independent variables to the dependent variable. The result signified that Nutritional Value Quality was able to clarify 72 percent $(p<.001)$ of the variance in culinarian's daily food preparation and consumption. By looking at the beta value, nutritive value quality $(\beta=78, p=0.00)$ had a slightly strong influence on chefs' daily food preparation and consumption.

Table 4.2 Multiple Regression Result

\begin{tabular}{l|l}
\hline & Beta Coefficients and Significance Levels \\
\hline Step 1: Model variable & \\
Nutritive Value & $.78^{* * *}$ \\
R2 & .716 \\
Adj.R2 & .713 \\
R2 change & .109 \\
F-change & 151.914 \\
\hline
\end{tabular}

\section{Conclusion}

As mentioned in the objective above, the result revealed that nearly all of the respondents agreed that nutritive value attributes are important and influence chefs' daily food preparation and consumption. In relation to the above statement, it is important for the chefs to enhance the quality of the food consumed by using fresh ingredients and the right cooking method in their daily food preparation and consumption. It is shown that cooking method will sustain nutrients in food while food ingredients that do not contain any food additive such as antibiotics, hormones, food colors, flavorings or preservative play a major role in healthy food consumption. Chefs do not only have knowledge about food ingredients and cooking skill, but they also have a huge opportunity to convey the knowledge and share culinary best practices to others. They are able to motivate the society towards better and healthier eating behavior and appreciate the culinary objective that can make a long-term impact on culinary education, health information, disease prevention, attitudes, and the general dietary habit of the society. 
Furthermore, the related authorities such as the culinary experts and chef association may also help to raise awareness about food quality among the society and food service provider. Also, as mentioned by Ibrahim, Ismail, \& Mohammed (2014), the chefs may offer advice and professional consultation to the society in relation to the preparation and consumption of high-quality food and provide training to enhance the presentation, variety and appeal of food served. In addition, educating the society on how to cook food based on dietary recommendations, especially among youths, allows them to develop critical thinking skills and technical proficiencies in order to follow dietary guidelines. Chefs' culinary knowledge and experience can be valuable and be utilized to encourage the industry's best practices so that they can prepare not only high-quality food but also sensory-acceptable meals for the consumers.

\section{Corresponding Author}

Khairunnisa Mohamad Abdullah. Faculty of Hotel and Tourism Management, Universiti Teknologi MARA, Puncak Alam Campus, 42300, Selangor, Malaysia.

Email: Khairunnisa1864@uitm.edu.my

\section{References}

Barrett, D. M., Beaulieu, J. C., \& Shewfelt, R. (2010). Color, Flavor, Texture, and Nutritional Quality of Fresh-Cut Fruits and Vegetable: Desirable Level, Instrumental and Sensory measurement, and the Effects of Processing. Food Science \& Technology, University of California, Davis, CA.

Bower, A. L. (1997). Recipes for Reading: Community Cookbooks, Stories, Histories. Amherst: University of Massachusetts Press, 105-117.

Buckleya, M., Cowana, C., \& McCarthyb, M. (2007). The Convenience Food Market in Great Britain: Convenience Food Lifestyle Segments.Vol.106, issue 2,106-127.

Condrasky, M., Ledikwe, J. H., Flood, J. E., \& Rolls, B. J. (2007). Chefs' opinions of restaurant portion sizes. Obesity, 15(8), 2086-2093.

Eves, A., Corney, M., Kipps, M., Lumbers, M., Price, M., \& Noble, C. (1996). The nutritional implications of food choices from catering outlets. Journal of Nutrition \& Food Science, 96(5), 26-29.

Ferree, M. (1973), What Is Food Quality? Journal of Food Distribution Research, 34- 36.

Gerbens-Leenes, W., \&Nonhebel, S. (2002). Food and land use. The influence of consumption patterns on the use of agricultural resources. University of Groningen, Netherlands.

Gharibyan, L. (2011). Functional Foods. International Food Information Council Foundation. Retrieved from www.foodinsight.org/foodsforhealth.aspx.

Gisslen, W. (2015). Professional Cooking. 8th Edition. Hoboken, New Jersey: John Wiley \&Sons, Inc Publisher.

Horska, E., \& Sparke K. (2007): Marketing attitudes towards the functional food and implications for market segmentation. Agricultural Economics - Czech, 53 (7): 349-353.

Ibrahim, U., Ismail, F. U., \& Mohammed, M. (2014). Nutritional Knowledge, Attitudes and Junk Food Consumption Habits among Students of AbubakarTatari Polytechnic (ATAP) Bauchi, Vol 5, 12.

Ikerd, J. (2008). The New American Food Economy.

Jarrard, E., \& Joe, L. (2014). Healthier Preparation Methods for Cooking. Retrieve from website http://www.heart.org. American Heart Association. 
Muhammad, R., Zahari, M. S. M., Othman, Z., Jamaluddin, M. R., \& Rashdi, M. O. (2009). Modernization and ethnic festival food. Paper presented at the International Conference of Business and Economic, Kuching, Sarawak.

Olsen, S. O. (2002). "Comparative evaluation and the relationship between quality, satisfaction, and repurchase loyalty." Journal of the Academy of Marketing Science 30 (3): 240-249.

Peri, C. (2006). The universe of food quality. Food Quality and preference. 17, 3-8.

Pratten, J. D. (2003). What makes a great chef?", British Food Journal, Vol. 105 No. 7, pp. 454-459. https://doi.org/10.1108/00070700310497255

Rickman, J. C., Bruhn, C., \& Barrett, D. M. (2007). Nutritional comparison of fresh, frozen and canned fruits and vegetables Part 1. Vitamin A and carotenoids, vitamin E, minerals and fibre. Journal of the Science of Food and Agriculture 87 (6): 930 - 944.

Schiefer, G., Deiter, J. (2013) Challenges and Experiences: Transparency for Sustainability in the Food Chain. https://doi.org/10.1016/C2013-0-01393-X

Sommerville, Kogan, P., \& Kerry, L. (2007). Hospitality Employee Management and Supervision, concepts and practical applications. New Jersey.

Usuramo, S. (2000). Fijian verbs of cooking. Journal of Educational Studies, 22(10), 114-124.

Zanoli, R. (2004). Consumers' attitudes, behaviours and strategic approaches in the European organic food market. University of Wales. 